\author{
키틴함유 DFMs 급여 한우송아지 분변내 키틴 및 키토산분해효소 생산 \\ 미생물 선발 및 동정 \\ 김태일* • 권응기* • 김형철* • 조영무* • 박병기* • 이원규** • 임석기* \\ 농촌진흥청 국립축산과학원*, (주)한동**
}

\title{
Screening and Isolation of Chitinase and Chitosanase Producing Microbes from the Feces of Korean Native Calves Medicated DFMs Including Chitin
}

\author{
Tae IL Kim*, Eung Gi Kwon*, Hyeong Cheol Kim*, Young Moo Cho*, Byung Ki Park*, Won Kyu Lee** \\ and Seok Ki Im* \\ Hanwoo Experiment Station, National Institute of Animal Science, RDA*, \\ Han Dong Co. Ltd**
}

\begin{abstract}
This study was carried out to screen and identify the chitinase and chitosanase producing microorganisms from the feces of calves medicated DFM sincluding chitin in order to do the immune fortification of Korean Native calves.

Ten isolates were grown in the medium containing chitin and chitosan that had more than $10^{5} \mathrm{cfu} / \mathrm{g}$ in feces. Among these 10 strains, 2 strains (HANDI 110 and HANDI 309) had the chitinase activities and 2 strains (HANWOO and HANYOO) had the chitosanase activities in calves' feces. They showed no reaction in hemolysis tests by utilizing chitin and chitosan. The results from morphological, physicochemical and genetical identification indicated the HANDI 110 as a strain of Escherichia fergusonii, HANDI 309 was identified as a strain of Acinetobacter parvus, HANWOO was identified as a strain of Comamonas koreensis, and HANYOO as a strain of Chryseobacterium indologenes.
\end{abstract}

(Key words : Korean Native Calves, Chtinase, Chitosanase, Microbes, Feces, DFMs)

\section{I . 서 론}

키틴은 지구상에서 섬유소 다음으로 풍부하게 존재하는 biomass로서 Chitin은 N-acetyl-D-glucosamine (GlcNAc)의 $\beta$ 1,4 결합을 기본구조로 하는 섬유상 중합체로서 직선상으 로 연결되어 있으며, 천연고분자 다당물질로서 갑각류의 껍질, 곤충의 외골격, 버섯류 및 사상균의 세포벽 등에 함 유되어 있다(Zikakis, 1984). 키토산은 키틴에서 acetyl amino기가 deacetylation된 알칼리 분해산물이다 $(\mathrm{Hsu}$ 와 Lockwood, 1975; Miller, 1987; 최 등, 2004). 키틴 및 키토 산은 독성이 없고 흡착성, 보습성, 유화성, 생분해성을 나 타내며 항균작용, 제산작용, 궤양억제작용, 콜레스테롤과 triglyceride를 낮추는 약리작용, 장내 유용세균의 생장촉진, 항종양활성, 식물세포의 활성화작용, 면역부활작용 등 다 양한 기능을 나타내는 것으로 알려지고 있으며 (Yabuki 등, 1987; Takayanagi 등, 1991; Zhu 등, 2003) 키틴내의 아 세틸아미노기는 강한 수소결합으로 이루어져 화학약품에
내성이 강하고 물이나 유기용매에 녹지 않은 특성이 있고 분해가 되면 N-acetyl-D-glucosamin의 기능성 때문에 오래 전부터 동서양을 막론하고 유용하게 이용되어오고 있다.

키틴을 분해하는 미생물의 동정과 함께 그 분해산물이 구명되면서 키틴 및 키토산으로부터 효소작용에 의해 얻 어진 glucosamine이 항생물질의 전구체로 이용된다는 점, 또한 생변환에 의한 단백질을 생산한다는 사실이 밝혀지 면서 키틴 및 키틴유도체가 식품산업, 제약산업, 농업 및 환경분야 등의 많은 분야에 활용되고 있다 (Juni, 1984; 박 등, 1995; Shimosaka 등, 1995; 정과 이, 1995; Harman 등, 1993; Hirano, 1989; Xu-fen Zhu, 2007).

Chitinase를 생성하는 미생물로는 Alteromonas, Serratia, Pseudomonas, Aeromonas, Enterococcus, Bacillus 등의 세균 (Hayashi 등, 1995; Sakai 등, 1998; 강과 정, 1999)과 Streptomyces 등의 방선균 (Mitsutomi 등, 1995), Tricodema, Aspergillus (Harman 등, 1993) 등의 사상균, Saccharomyces 등의 효모(Mollogy와 Burke, 1997) 등이 알려져 있다.

Corresponding author: Tae IL Kim, Hanwoo Experiment Station, National Institute of Animal Science, RDA, Gangwon 232-950, Korea. E-mail: kimti@korea.kr 
Chitinase를 산업적으로 응용하기 위해서는 Chitinase 생산능 이 높은 균주의 탐색이 우선시 되어야 한다. Sakai 등(1998) 은 키틴이 함유된 퇴비에서 키틴유용미생물을 분리하여 폐 기물처리에 활용하는 등 Chitin 분해 미생물에 관한 연구는 생물농약 및 폐기물처리 등에는 매우 활발하게 이루어지고 있으나 가축에 이용 등에 관련된 연구는 전무한 상태이다.

따라서, 본 연구는 키틴으로부터 면역증강물질인 glucosamine을 가축의 체내에 축적시킴으로써 동물의 면역력을 향상시켜 폐사율을 줄이고자 키틴이 함유된 $\mathrm{DFMs}$ 를 급여 한 생후 3 7개월령된 한우 송아지의 분변에서 키틴분해 효소능을 가진 분변내 미생물을 분리 동정함으로서 이를 산업화하기 위한 기초자료로 활용하고자 수행하였다.

\section{ㅍ. 재료 및 방법}

\section{1. 키틴 및 키토산 분해 균주 선발}

키틴을 분해하는 미생물을 분리하기 위해서 키틴을 함유 한 $\mathrm{DFMs}$ 을 급여한 송아지 분변에서 시료를 채취한 다음 Sakai (1998)의 방법에 따라 삼각플라스크 $500 \mathrm{ml}$ 에 Table 1 과 Table 2의 배지에서 agar를 제외한 액체배지 $100 \mathrm{ml}$ 씩을 넣 고 한우 송아지 분변을 각 $1 \mathrm{~g}$ 씩 접종하여 $30^{\circ} \mathrm{C}$ 에서 5 일간 진탕배양한다. 액체배양액을 peptone 수(peptone $1 \%, \mathrm{NaCl}$

Table 1. Selective medium for Chitinase producing microbes

\begin{tabular}{cc}
\hline Ingredients & Concentration (\%, w/v) \\
\hline \hline Chitin & 1.0 \\
Yeast extract & 0.1 \\
$\mathrm{~K}_{2} \mathrm{HPO}_{4}$ & 0.07 \\
$\mathrm{KH}_{2} \mathrm{PO}_{4}$ & 0.03 \\
$\mathrm{MgSO}_{4} \cdot 7 \mathrm{H}_{2} \mathrm{O}$ & 0.01 \\
$\mathrm{FeSO}_{4} \cdot 7 \mathrm{H}_{2} \mathrm{O}$ & 0.01 \\
Agar & 1.5 \\
\hline
\end{tabular}

Table 2. Selective medium for Chitosanase producing microbes

\begin{tabular}{cc}
\hline Ingredients & Concentration (\%, w/v) \\
\hline \hline Chitosan & 1.0 \\
Yeast extract & 0.1 \\
$\mathrm{~K}_{2} \mathrm{HPO}_{4}$ & 0.07 \\
$\mathrm{KH}_{2} \mathrm{PO}_{4}$ & 0.03 \\
$\mathrm{MgSO}_{4} \cdot 7 \mathrm{H}_{2} \mathrm{O}$ & 0.01 \\
$\mathrm{FeSO}_{4} \cdot 7 \mathrm{H}_{2} \mathrm{O}$ & 0.01 \\
Agar & 1.5 \\
\hline \multicolumn{2}{c}{ Adjust to $\mathrm{pH} 7.0$} \\
\hline
\end{tabular}

$0.5 \%, \mathrm{pH}$ 7.2) 10 배 희석법으로 연속적으로 희석한 후 각 희석액을 키틴 및 키토산이 함유된 고체배지에 도말하여 30 ${ }^{\circ} \mathrm{C}$ 에서 배양하면서 출현된 colony 주위에 형성된 chitin 및 chitosan 분해환 형성 균주를 분리하였다. 이때 각 효소의 생산능은 Vipul 등 (2005)의 방법에 따라 Congo red로 염색 하여 확인하였다. 키틴 및 키토산 분해 균주 선발을 위해 사용된 배지의 조성은 Table 1과 Table 2와 같다. 분리된 균 은 사용하기 전까지 glycerol이 함유된 Nutrient broth에 배양 한 다음 $-20^{\circ} \mathrm{C}$ 보관하여 키틴유용성 조사에 이용하였다.

\section{Hemolysis 측정}

각각의 배지에서 무작위로 형태가 다른 콜로니들을 선 별 - 분리하여 RBA(Heart infusion agar $+5 \%$ Sheep blood) 배지에 patching 방법으로 도말한 후 배지상에 나타나는 hemolysis 형상을 관찰하였다. 콜로니 주변에 부분적인 녹 색투명대를 형성하는 것을 $\mathrm{a}-$ 용혈로, 콜로니 주변에 상당 히 넓게 누런 투명대를 형성하는 것을 $\beta$-용혈로, 용혈현 상이 나타나지 않아 투명대가 없을 때를 $\gamma$-용혈로 표시하 였다 (Facklam과 Wilkinson 1981).

\section{3. 분리균주의 유전학적 특징}

(1) PCR Amplification, 16S rDNA sequencing 및 Phylogenetic 분석

분리 균주의 $16 \mathrm{~S}$ ribosomal DNA sequencing은 다음과 같은 방법으로 수행하였다. 본 실험 균주의 chromosomal DNA을 Wizard genomic DNA purification kit (Promega, USA)를 이용해 분리한 후 $16 \mathrm{~S}$ rRNA sequencing에 사용하 는 universal primer인 27F (5'-AGAGTTTGATCATGGCTCAG-3') 와 1492R (5'-GGATA CCTTG TTACGACTT-3') primer를 사 용하여 PCR 증폭하였다(Yoon 등 1996). 증폭된 PCR 산물 은 Wizard SV Gel and PCR clean-up system(Promega, $\mathrm{USA}$ )을 이용하여 정제하였다. 정제된 $\mathrm{PCR}$ 산물은 $\mathrm{ABI}$ PRISM 3730 DNA Analyzer를 이용하여 염기서열을 분 석하였다. 그 결과는 BLASTN 프로그램을 이용하여 GENEBANK의 ribosomal DNA sequence와 비교하였으며, sequence의 상동성은 Clustal X와 Mega 2 program을 이용 하여 비교분석하였다 (Thompson 등, 1994).

(2) 염기조성 측정 $(\mathrm{G}+\mathrm{C} \mathrm{mol} \%)$

$\mathrm{DNA}$ 의 염기 조성을 측정하기 위해서 Katayama-Fujimura 등 (1984)과 Tamaoka와 Komagata (1984)의 방법에 따라 분 리된 $\mathrm{DNA}(1 \mathrm{mg} / \mathrm{ml})$ 를 eppendorf tube에 녹인 후 $100^{\circ} \mathrm{C}$ 의 끓은 물에 5 분간 넣어 $\mathrm{DNA}$ 를 변성시킨다. 새로운 eppendorf tube에 열 변성된 DNA를 $10 \mu \ell$ 분주한 후 
nuclease $\mathrm{P} 1\left(0.1 \mathrm{mg} / \mathrm{ml}\right.$ in $40 \mathrm{mM}$ Na-actate $+2 \mathrm{mM} \mathrm{ZnSO}_{4}$ solution, $\mathrm{pH}$ 5.3)을 $10 \mu$ 를 첨가하여 30 분간 반응시켜 deoxyribonucleotide 상태로 되게 한 후 $10 \mu$ 의 alkaline phosphatase solution $(2.4 \mathrm{unit} / \mathrm{ml}$ in $0.1 \mathrm{M}$ Tris-Hcl buffer, $\mathrm{pH}$ 8.1 를 첨가하여 $37^{\circ} \mathrm{C}$ 에서 60 분간 반응시킴으로서 nucleoside로 만든 후 Table 3 의 조건의 HPLC에서 분석하였다.

Table 3. Conditions of HPLC for analysis of DNA base composition

\begin{tabular}{ll}
\hline Column & $\begin{array}{l}\text { Beckman ULTRASPHERE ODS } \\
(4.6 i . d . ~ X ~ 250 \mathrm{~mm})\end{array}$ \\
\hline Column temperature & $30^{\circ} \mathrm{C}$ \\
\hline Mobile phase & $30 \mathrm{mM} \mathrm{KH} \mathrm{PO}_{4}(\mathrm{pH} \mathrm{2.8})$ \\
\hline Flow rate & $1.0 \mathrm{ml} / \mathrm{min}$ \\
\hline & $\begin{array}{l}\text { Beckman Programmable Detector } \\
\text { Medule 166 with Diode Array } \\
\text { Detector }\end{array}$ \\
\hline Data analyzer & Beckman \\
\hline
\end{tabular}

\section{4. 미생물의 동정}

키틴 및 키토산 분해능이 우수한 선발균주를 동정하기 위해 분리균의 형태, 생리, 생화학적 특성을 Bergey's Manual of Systematic Bacteriology (Krieg와 Holt, 1984), Bergey's Manual of determinative bacteriology (Holt 등, 1994)와 Microbiological Application(Benson, 1990)에 따라 조사하였고 유전학적 특성을 통해 선발균주를 동정하였다.

\section{III. 결과 및 고찰}

\section{1. 배양학적 및 형태학적 특성}

키틴과 키토산의 유용성이 우수한 송아지 분변내 미생 물을 10 균주 중 각각 2균주를 선발하였으며, Nutrient 한천 평판배지 및 Nutrient 액체배지에 접종하여 $37^{\circ} \mathrm{C}$ 에서 24
48시간 동안 배양하면서 집락형태, 색깔, 표면상태, 광택, 가장자리 및 생육상태 등 배양상 특성을 관찰하였다. 선 발균주의 배양학적 특성은 Nutrient broth에서 침전이나 pellicle이 없이 성장하였으며, Nutrient agar상에서 HANDI 110은 yellow였고 HANDI 309는 Bright beige, HANWOO는 Creamy, HANYOO는 Strong yellow의 색을 지녔다. 선발균 주의 배양학적 특성은 Table 4와 같다. Fig. 1과 같이 Chitinase를 생산하는 균주로 분해환을 보인 HANDI 110는 간균이였으며 HANDI 309는 구균으로 모두 그람 음성균으 로서 운동성과 포자형성은 없었다. Chitosanase를 생산하는 균주로 분해환을 보인 HANWOO와 HANYOO는 그람음성 의 간균이였으며 운동성과 포자는 형성하지 않았다. 선발 균주의 형태학적 특징은 Table 5와 같다.

\section{2. 분리균주의 물리화학적 성상}

선발균주를 동정하기 위해서 4 개 균주의 물리화학적인 성상을 구명하였다.

최적성장온도를 구명하기 위해서 Nutrient 사면배지에 접종한 후 각각 다른 온도에서 72시간 동안 배양하며 생 육 여부를 관찰하였다. 4 종의 선발균주 모두가 $30^{\circ} \mathrm{C}$ 에서 최적온도였으며, 생육 $\mathrm{pH}$ 범위를 구명하기 위해서 멸균한 Nutrient 액체배지에 $\mathrm{pH}$ 를 $\mathrm{HCl}$ 과 $\mathrm{NaOH}$ 로 3 11로 조절하 고, 균주를 접종한 후 $37^{\circ} \mathrm{C}$ 에서 72 시간 동안 배양시키면

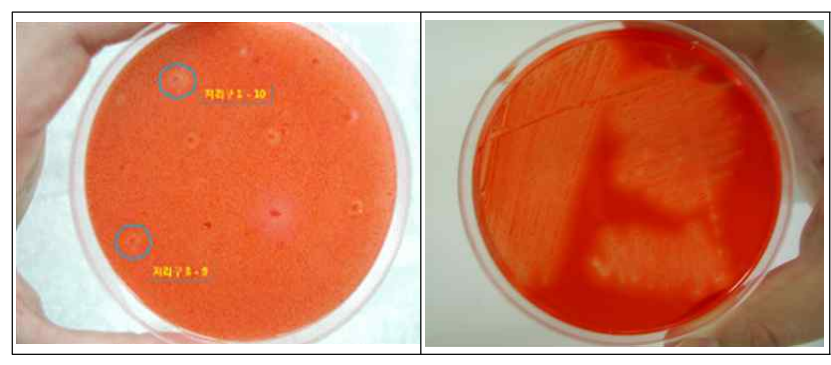

Fig. 1. Chitinolytic (Left) and Chitosanolytic (Right) Clear zone produced by the isolates.

Table 4. Cultural characteristics of strains

\begin{tabular}{|c|c|c|c|c|c|}
\hline \multirow{2}{*}{\multicolumn{2}{|c|}{ Factors }} & \multicolumn{4}{|c|}{ Characteristics } \\
\hline & & HANDI 110 & HANDI 309 & HANWOO & HANYOO \\
\hline \multirow{7}{*}{$\begin{array}{l}\text { Colony on } \\
\text { the Nutrient agar } \\
\left(35^{\circ} \mathrm{C}, 1 \sim 2 \text { days }\right)\end{array}$} & Form & Circular & Circular & Spindle & Circular \\
\hline & Surface & Smooth & Smooth & Smooth & Smooth \\
\hline & Edge & Entire & Entire & Entire & Entire \\
\hline & Elevation & Erose & Convex & Convex & Convex \\
\hline & Opacity & Opaque & Opaque & Opaque & Opaque \\
\hline & Pigment & Yellow & Bright beige & Creamy & Strong yellow \\
\hline & Briliancy & Glistening & Glistening & Glistening & Glistening \\
\hline \multirow{2}{*}{\multicolumn{2}{|c|}{$\begin{array}{l}\text { Growth on Nutrient } \\
\text { broth }\left(35^{\circ} \mathrm{C}, 1 \sim 2 \text { days }\right)\end{array}$}} & +++ & ++ & +++ & +++ \\
\hline & & \multicolumn{4}{|c|}{ Turbid without pellicle and not sediment } \\
\hline
\end{tabular}


Table 5. Morphological characteristics of strains

\begin{tabular}{lcccc}
\hline \multirow{2}{*}{ Factors } & \multicolumn{4}{c}{ Characteristics } \\
\cline { 2 - 5 } & HANDI 110 & HANDI 309 & HANWOO & HANYOO \\
\hline \hline Shape & Rod & Coccus & Rod & Rod \\
\hline Motility & - & - & - & - \\
\hline Spore & - & - & - & - \\
\hline Gram stain & - & - & & - \\
\hline+ ; Positive - ; Negative. & & &
\end{tabular}

Table 6. Physicochemical characteristics of strains

\begin{tabular}{|c|c|c|c|c|}
\hline \multirow{2}{*}{ Factors } & \multicolumn{4}{|c|}{ Characteristics } \\
\hline & HANDI 110 & HANDI 309 & HANWOO & HANYOO \\
\hline Optimum Temperature & $30^{\circ} \mathrm{C}$ & 30 & 30 & 30 \\
\hline Assimilation of L-Arabinose & + & - & - & + \\
\hline Cellulose & - & - & - & - \\
\hline Dextrin & + & + & + & - \\
\hline Fructose & + & - & - & + \\
\hline Glucose & + & + & - & + \\
\hline Lactose & + & - & - & - \\
\hline D-Maltose & + & - & - & + \\
\hline Mannitol & + & - & - & - \\
\hline Soluble starch & - & + & - & + \\
\hline Sucrose & + & - & - & + \\
\hline Xylose & + & - & - & + \\
\hline $\mathrm{pH}$ range for growth & $5 \sim 10$ & $6 \sim 10$ & $5 \sim 10$ & $5 \sim 10$ \\
\hline Catalase & + & + & + & + \\
\hline Oxidase & - & - & - & - \\
\hline Urease & - & + & - & + \\
\hline Lipase (Tween 80 hydrolysis) & - & - & - & - \\
\hline Arginine dihydrolase & - & - & - & - \\
\hline Phenylalanine deaminase & - & - & - & - \\
\hline & - & + & + & + \\
\hline Casein & - & + & + & + \\
\hline Esculin & + & NG & NG & NG \\
\hline Indole production & + & - & - & + \\
\hline $\mathrm{H}_{2} \mathrm{~S}$ production on TSI agar (color/gas) & $-1+$ & $-1-$ & $-1-$ & $-1-$ \\
\hline Levan formation from sucrose & - & - & - & - \\
\hline $\mathrm{NH}_{3}$ production from peptone & - & - & - & + \\
\hline $\mathrm{NH}_{3}$ production from arginine & + & + & + & + \\
\hline Gelatin liquefaction & - & - & - & + \\
\hline Utilization of citrate & - & - & - & - \\
\hline Methyl red test & + & $\mathrm{NG}$ & - & - \\
\hline Voges-Proskauer test & + & NG & - & - \\
\hline Nitrate reduction & + & - & - & - \\
\hline Denitrification & + & + & + & + \\
\hline \multirow{2}{*}{$\begin{array}{l}\text { Action on milk ; } \begin{array}{l}\text { coagulation } \\
\text { peptonization }\end{array} \\
\end{array}$} & + & - & - & - \\
\hline & - & - & - & - \\
\hline O-F test & + & - & - & - \\
\hline Hemolysis & - & - & - & - \\
\hline
\end{tabular}

* NG; not growth, +; Positive -; Negative 
서 생육 여부를 관찰한 결과 HANDI 110, HANWOO, $\mathrm{HANYOO}$ 는 5 10의 범위에서 성장하였고, HANDI 309는 6 10의 범위에서 생육함이 관찰되었다. 선발균주 4종 모 두 Catalase test는 양성, Oxidase는 음성이였고 Citrate를 이 용하지 못하였으며 용혈환을 생성하지 않았다. Basal Medium $\left(\mathrm{NH}_{4} \mathrm{NO}_{3} 1 \mathrm{~g}, \mathrm{KH}_{2} \mathrm{PO}_{4} 1 \mathrm{~g}, \quad \mathrm{MgSO}_{4} \cdot 7 \mathrm{H}_{2} \mathrm{O} \quad 0.5 \mathrm{~g}\right.$, $\mathrm{KCl} 0.2 \mathrm{~g}$, 증류수 $1,000 \mathrm{ml}, \mathrm{pH}$ 7.2)에 별도로 멸균한 각종 의 당액을 최종농도가 $1 \%(\mathrm{w} / \mathrm{v})$ 씩 되게 첨가한 후 각각의 균주를 접종하여 $37^{\circ} \mathrm{C}$ 에서 7 일간 배양하면서 균주의 생육 상태를 당을 첨가하지 않은 대조구와 비교하여 관찰한 결 과 HANDI 110은 Arabinose, Dextrin, Fructose, Glucose, Lactose, Maltose, Mannitol, Sucrose를 이용하였고, HANDI 309는 Dextrin, Glucose, Soluble starch를, HANWOO는
Dextrin만을, HANYOO는 Arabinose, Fructose, Glucose, Maltose, Soluble starch, Sucrose, Xylose를 이용하였다. 분리 균주의 물리화학적인 성상은 Table 6과 같다.

\section{3. 분리균주의 유전학적 특징}

분리균주별 Genomic DNA의 $\mathrm{G}+\mathrm{C}$ 함량과 $16 \mathrm{~S} \mathrm{rDNA}$ 상 동성는 $\mathrm{HANDI} 110$ 의 경우 $\mathrm{G}+\mathrm{C} \mathrm{mol} \%$ (HPLC)는 $55.32 \%$ 였 고 Gene Bank Data의 Escherichia fergusonii ATCC 35469 $\mathrm{AF} 530475$ 와 Homology가 $99 \%$ 로 나타났다. 그 결과는 Fig. 2와 같다. HANDI 309는 $\mathrm{G}+\mathrm{C} \mathrm{mol} \%$ (HPLC)는 45.43\%였고 Gene Bank Data의 Acinetobacter parvus LUH4616AJ 293691 과 Homology가 $96 \%$ 로 나타났다. 그 결과는 Fig. 3과 같다.

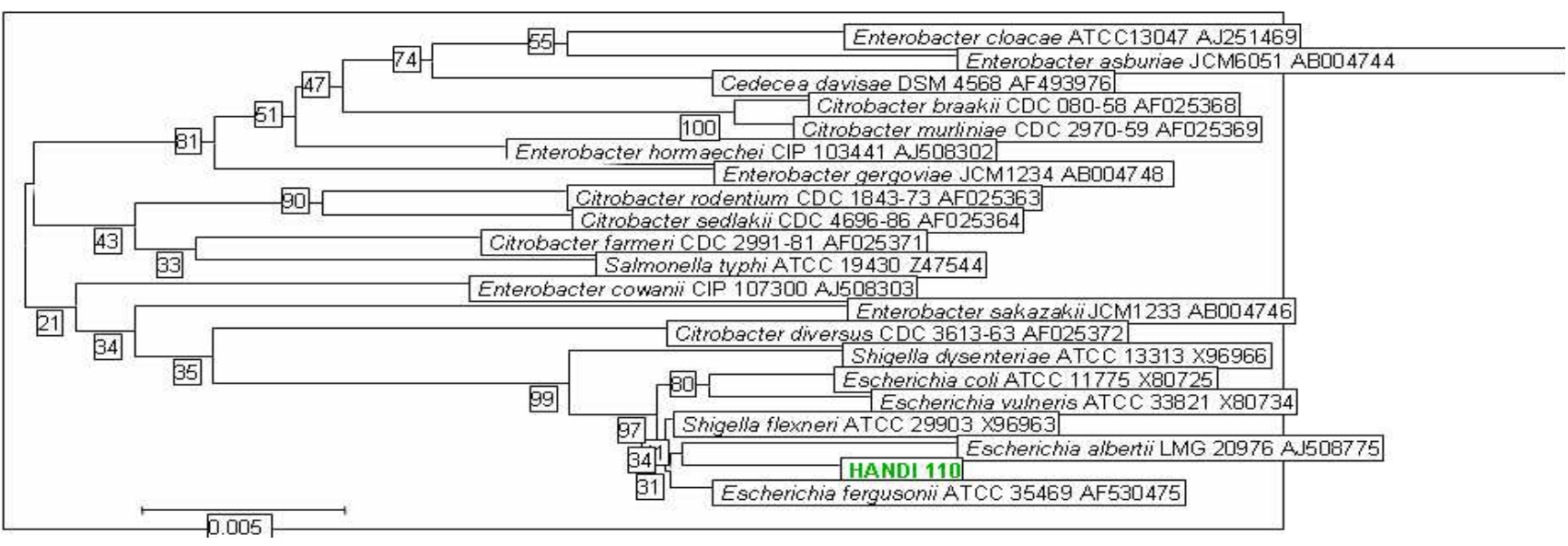

Fig. 2. Phylogenetic tree constructed from a comparative analysis of $16 \mathrm{~S}$ rRNA gene sequences of the strain HANDI 110 with other related species.

This tree was made using the GeneBank Database. Bar, 0.005 substitutions per 1nucleotide position.

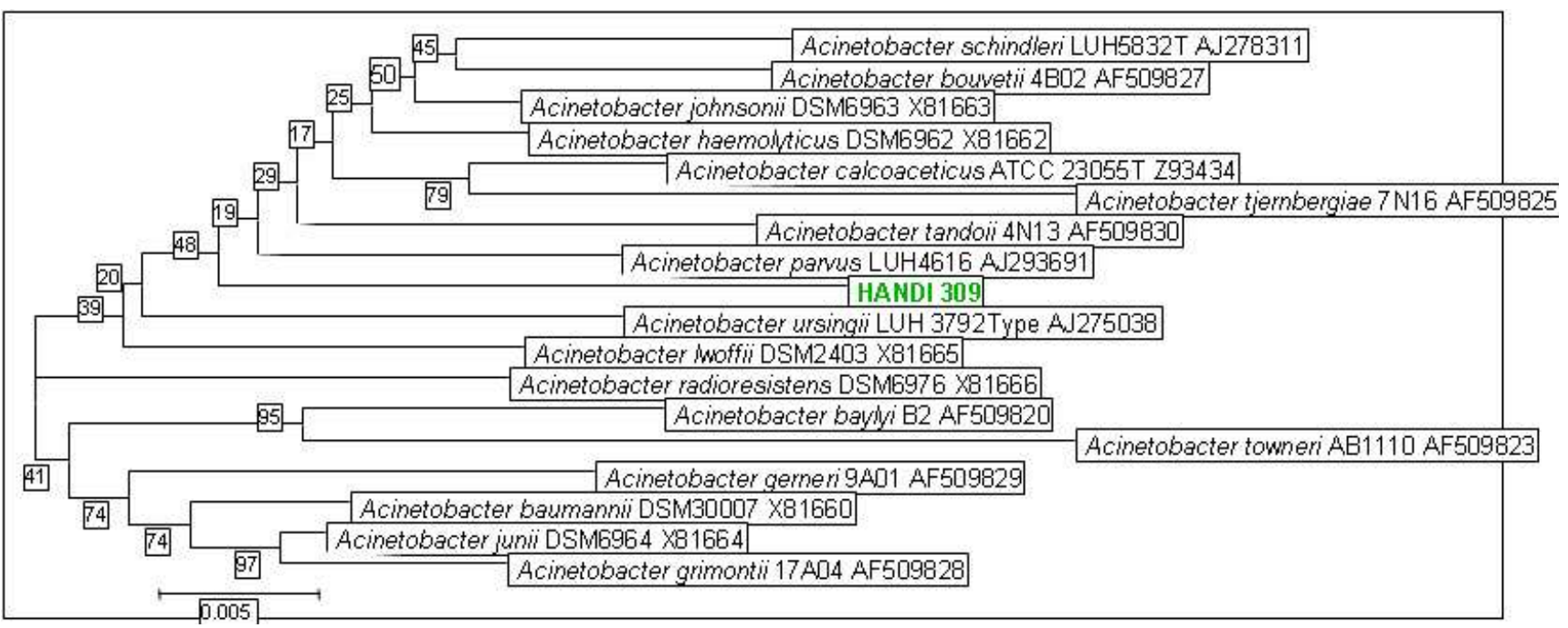

Fig. 3. Phylogenetic tree constructed from a comparative analysis of $16 \mathrm{~S}$ rRNA gene sequences of the strain HANDI 309 with other related species.

This tree was made using the GeneBank Database. Bar, 0.005 substitutions per 1 nucleotide position. 
HANWOO는 $\mathrm{G}+\mathrm{C}$ mol\% (HPLC)는 66.14\%였고 Gene Bank Data의 Comamonas koreensis과 $\mathrm{KCTC} 12005 \mathrm{AF} 275377$ 과 Homology가 $99 \%$ 로 나타났다. 그 결과는 Fig. 4와 같다. $\mathrm{HANYOO}$ 는 $\mathrm{G}+\mathrm{C}$ mol\% (HPLC)는 42.29\%였고 Gene Bank Data의 Chryseobacterium indologenes ATCC29897 M58773과 Homology가 $98 \%$ 로 나타났다. 그 결과는 Fig. 5와 같다.

\section{4. 분리균주의 동정}

분리균주의 물리화학적 특성 및 유전학적 특성을 통해 키틴 유용균인 HANDI 110과 HANDI 309는 각각 Escherichia fergusonii HANDI 110과 Acinetobacter parvus
HANDI 309로 명명하였으며, 키토산 유용균인 HANWOO 와 $\mathrm{HANYOO}$ 는 각각 Comamonas koreensis HANWOO와 Chryseobacterium indologenes HANYOO로 명명하였다. 염 기조성에 있어서 미생물의 경우 $25 \sim 75 \%$ 의 넓은 $\mathrm{G}+\mathrm{C}$ 분 포를 나타내고 있지만 Marmur와 Doty (1962)가 DNA의 염 기조성의 분석방법을 발표한 이후로 미생물 종 (Species)단 계 분류의 주요한 인자로 정착되었다. 본 실험에서 분리 한 미생물 4종의 $\mathrm{G}+\mathrm{C}$ 함량은 미생물을 동정시 표준균주 로 제시하고 있는 Bergey's Manual of Systematic Bacterio$\operatorname{logy}$ (Krieg N.R과 J.G Holt, 1984)과 Bergey's Manual of determinative bacteriology (Holt 등, 1994)를 참조하여 차이 가 없어 동일한 염기서열이라고 판단되어 진다. 미생물의

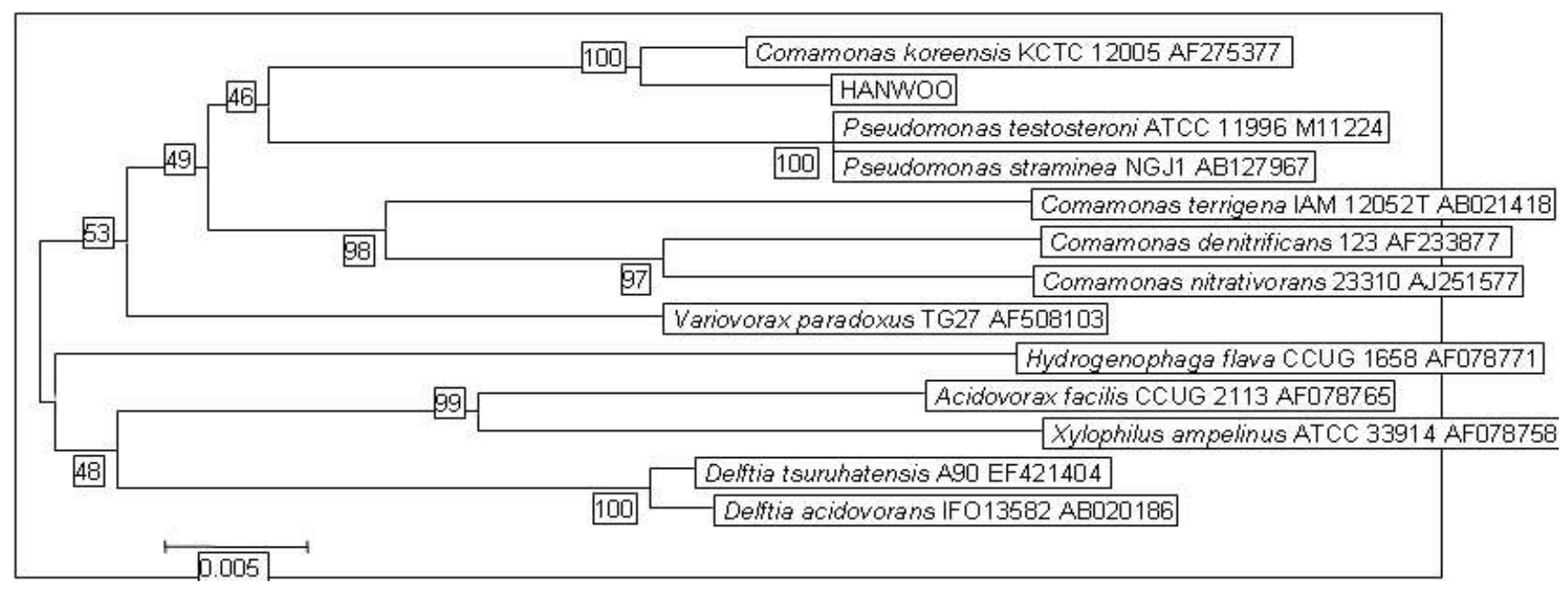

Fig. 4. Phylogenetic tree constructed from a comparative analysis of $16 \mathrm{~S}$ rRNA gene sequences of the strain HANWOO with other related species.

This tree was made using the GeneBank Database. Bar, 0.005 substitutions per 1 nucleotide position.

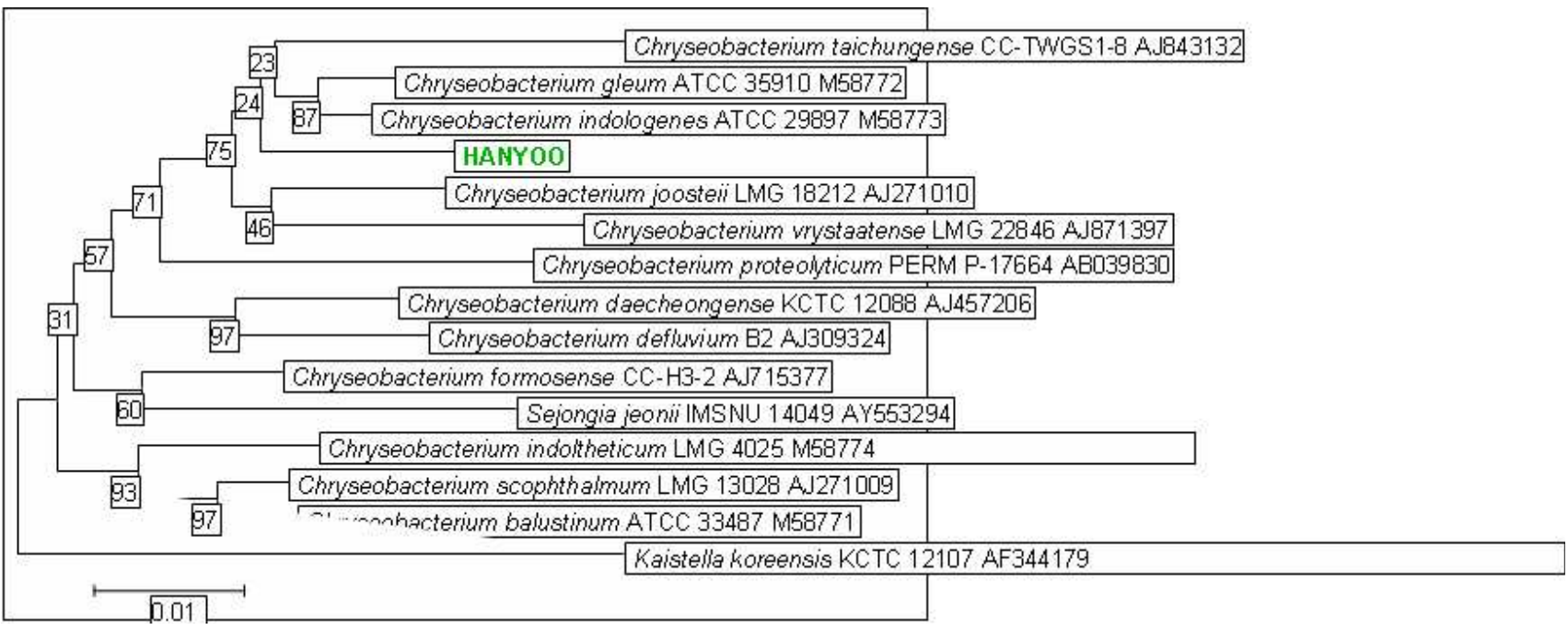

Fig. 5. Phylogenetic tree constructed from a comparative analysis of $16 \mathrm{~S}$ rRNA gene sequences of the strain HANYOO with other related species.

This tree was made using the GeneBank Database. Bar, 0.01 substitutions per 1 nucleotide position. 
분류학상 동일한 속인 경우 $\mathrm{GC}$ 함량의 범위가 $10 \%$ 이내, 동일한 종일 경우 $3 \%$ 이내의 범위에 분포하고 DNA Homology가 $70 \%$ 이상의 Homology치를 나타내면 동일한 종으로 보고 있다.

Crude 키틴을 이용하여 분리 및 동정한 이들 균종을 산 업화하기 위해선 효소생산을 위한 최적조건의 구명과 함 께 분해산물의 특성 등에 대한 연구가 좀 더 이루어져야 할 것으로 여겨진다.

$$
\text { IV. 요 약 }
$$

본 연구는 키틴으로부터 면역증강물질인 N-acetyl-Dglucosamine을 축적시킴으로써 동물의 면역력을 향상시켜 폐사율을 줄이고자 키틴이 함유된 $\mathrm{DFM}$ 을 급여한 생후 3 7개월령된 한우 송아지의 분변에서 키틴분해 효소능을 가진 미생물을 분리 동정하기 위해서 수행하였다.

송아지 분변 $1 \mathrm{~g}$ 당 키틴이 함유된 배지상에서 $10^{5}$ 이상 의 집락이 형성된 10 균주 중 키틴을 분해하는 2 균주와 키 토산을 분해하는 2균주를 선발하였으며 이들은 모두 용혈 성을 갖지 않는 것으로 나타났다. 키틴을 분해하는 균주 는 선발한 4균주 모두 그람 음성균으로서 HANDI 110과 HANDI 309는 키틴을 분해하는 균주로 선발되었으며 HANWOO와 HANYOO는 키토산을 분해하는 균주로 선 발되었다.

분리된 미생물은 형태학적, 물리화학적 및 유전학적 분 류를 통해 HANDI 110는 Escherichia fergusonii으로, HANDI 309는 Acinetobacter parvus으로, HANWOO는 Comamonas koreensis으로 HANYOO는 Chryseobacterium indologenes으로 각각 동정하였다.

\section{$\mathrm{V}$. 인 용 문 헌}

1. Benson, H. J. 1990. Identification of unknown bacteria. In Microbiological application, 5th ed. W. C. Brown Publishers. USA, pp 146-173.

2. Choi, Y. J., Kim, E. J., Piao, Z., Yun, Y. C. and Shin, Y. C., 2004. Purification and characterization of chitosanase from Bacillus sp. strain KCTC 0377BP and its application for the production of chitosan oligosaccharides. Appl. Environ. Microbiol. $70(8): 4522-4531$.

3. Facklam, R. and Wilkinson, H. W. 1981. The family Streptococcaceae. In M. P. Starr, H. Stolp, H. G. Truper, A. Balows and H. G,. Schlegel (Eds.) The prokaryotes. Springer-Verlag. Berlin.pp. 1572.

4. Hayashi, K., Sato, S., Takano, R., Tsujibo, H., Orikoshi, H., Imada, C., Okami, Y., Inamori, Y. and Hara, S. 1995.
Identification of the positions of disulfide bonds of chitinase from a marine bacterium, Alteromonas sp. Strain O-7. Biosci. Biotech. Biochem. 59:1981-1982.

5. Harman, G. E., Hayes, M., Lorito, Broadway, R. M., Dipietro, A., Peterbauer, C. and Tronsmo, A. 1993. Chitinolytic enzymes of Trichoderma harzianum; Purification of chitobiosidase and endochitinase. Phytopathology 83:313-318.

6. Hirano, S. Chitin and Chitosan. Essex: Elsevier; 1989. Production and Application of Chitin and Chitosan in Japan; pp. 37-43.

7. Holt, J. G., Krieg N. R., Sneath, P. H. A., Staley, J. T. and Williams, S. T. 1994. Bergey's Manual of determinative bacteriology 9th Eds., Williams \& Wilkins, Baltimore.

8. Hsu, S. C. and Lockwood, L. 1975. Powdered chitin agar as a selective medium for enumeration of Actinomycetes in water soil. Appl. Microbiol. 29, 422-426.

9. Juni, E. 1984. Genus III. Acinetobacter, p. 303-307. In N. R. Krieg and J. G. Holt (ed.), Bergey's manual of systematic bacteriology, vol. 1. The Williams \& Wilkins Co., Baltimore.

10. Katayama-Fujimura, Y., Komatsu, Y., Kuraishi, H. and Kaneko, T. 1984. Estimation of DNA base composition by high performance liquid chromatography of its nuclease P1 hydrolysate. Agric. Biol. Chem. 48:3169-3172.

11. Krieg N. R. and Holt, J. G. 1984. Bergey's Manual of Systematic bacteriology, Vol 1 Eds., Williams \& Wilkins, Baltimore.

12. Marmur, J. and Doty, P. 1962. Determination of base composition of DNA from its thermal denaturation temperature. J. Mol.Biol. 5: 109-118.

13. Miller, L. 1987. Use of dinitrosalicylic acid reagent for determination of reducing sugar. Anal. Chem. 31, 425-431.

14. Mitsutomi, M., Hata, T., Kuwahara, T. 1995. Purification and characterization of novel chitinases from Stereptomyces griseus HUT 6037. J. Ferment. Bioeng. 80:153-158.

15. Mollogy, C. and Burke, B. 1997. Expression and secretion of Janthinobacterium lividum chitinase in Saccharomyces cerevisiae. Biotech. Lett. 19:1161-1164.

16. Sakai, K., Yokota, A., Kurokawa, H., Wakayama, M. and Moriguchi, M. 1998. Purification and characterization of three thermostable endochitinases of a noble Bacillus strain, MH-1, isolated from chitin-containing compost. Appl. Environ. Microbiol. 64: 3397-3402.

17. Shimosaka, M., Nogawa, M., Wang, X. Y., Kumehara, M. and Okazaki, M. 1995. Production of two chitosanases from a chitosan-assimilating bacterium, Acinetobacter sp. strain CHB101. Appl. Environ. Microbiol. 61:438-442.

18. Takayanagi, T., Ajisaka, K., Tabiguchi, T. and shimakara, K. 
1991. Isolation and characterization of thermostable chitinase

from Bacillus licheniformis X-7u. Biochim. Biophys. Acta. 1078, 410-414.

19. Tamaoka, J. and Komagata, K. 1984. Determination of DNA base composition by reverse-phase high performance liquid chromatography. FEMS Microbio. Lett 25:125-128.

20. Thompson, J. D., Higgins, D. G. and Gibson, T. J. 1994. CLUSTAL W: improving the sensitivity of progressive multiple sequence alignment through sequence weighting, positionspecific gap penalies and weight matrix choice. Nucleic Acids Res. 22, 4673-4680.

21. Vipul G., Pranav V. and Chatpar, H. S. 2005. Activity staning method of chitinase on chitin agar plate through polyacrylamide gel electrophoresis. African J. of Biotechnology 4(1):87-90.

22. Yabuki, M., Hirano, M., Ando, A., Fujii, T. and Amemiya, Y. 1987. Isolation and characterization of a chitosan degrading bacterium and formation of chitosanase by the isolate. Tech. Bull. Fac. Hort. Chiba Univ. 39, 23-27.

23. Yoon, J. H., Lee, S. T. and Park, Y. H. 1996. Inter-and intraspecific phylogenetic analysis of the genus Nocardioides and related taxa based on $16 \mathrm{~S}$ rDNA sequences. Int. J. Syst.
Bacteriol. 48, 187-194.

24. Zikakis, J. P. 1984. Chitinase from soybean seeds; Purification and some properties of the enzyme system Wadworth, S. A., J. P. Zikakis. J. Agric. Food Chem. 32:1284-1288.

25. Zhu, X. -F., Wu, X. -Y. and Dai, Y. 2003. Fermentation condition and properties of chitosanase from Acinetobacter sp. C-17. Biosci. Biotechnol. Biochem. 67, 284-290.

26. Zhu, X.-F., Ying Zhou, and Jun-li Feng. 2007. Analysis of both chitinase and chitosanase produced by Sphingomonas sp. CJ-5. J Zhejiang Univ Sci B. 8(11):831-838.

27. 강신욱, 정만재. 1999. Pseudomonas uesicularis KW-15가 생 산하는 Chitinase의 정제. 한국키틴키토산학회지 4(3):132-136.

28. 박서기, 이효연, 김기청. 1995. 토양전염성 식물병원균에 대 한 Chitin 분해세균들의 길항효과. 한국식물병리학회지 11(1): 47 52.

29. 정의준, 이용현. 1995. Chitooligosaccharides생산에 적합한 Chitinase를 분비하는 균주의 선별, Chitinase의 분리정제 및 반응특성. 한국산업미생물학회지. 23(2):187-196.

(접수일자 : 2009. 9. 4. / 수정일자 : 2009. 10. 20. /

채택일자 : 2009. 10. 20.) 